\title{
粘性系ダンパーを用いた免震構造物の非線形定常振動 NON-LINEAR STEADY-STATE VIBRATION OF SEISMICALLY-ISOLATED STRUCTURES WITH VISCOUSLY-DAMPED ISOLATION SYSTEMS
}

\author{
菊地 優*, 田村和夫**, 上田正生*** \\ Masaru KIKUCHI, Kazuo TAMURA and Masaiki UEDA
}

\begin{abstract}
The study of the steady-state vibration of a system under sinusoidal excitation can provide important insights into the more general dynamic response of structures. This paper presents the non-linear steady-state vibration of seismically-isolated structures with viscously-damped isolation systems. The study is conducted using a simple 2-DOF model with non-linear superstructure springs. The solution method for the steady-state vibration of the non-linear system is based on the work of (aughey ${ }^{1)}$, and expanded to seismically-isolated structures. The non-linear superstructure behavior is significantly different from that of a fixed-base structure. Consequently, some important aspects for design of seismically-isolated structures are highlighted.
\end{abstract}

Keywords: $\quad$ seismic isolation, non-linear, steady-state vibration, viscous damping, ductility factor 免震，非線形，定常振動，粘性減衰，塑性率

1.はじめに

調和地動が作用する振動系の定常応答は構造物の基本的応答特性 を理解する上で重要である。Caugheyによる非線形復元力を有する 1 質点振動系の定常振動に関する研究 ${ }^{1)}$ からは、構造物の塑性化に 伴う共振振動数の低下、塑性吸収エネルギーによる忍答変位の減少、 最適降伏震度の存在が見出されるなど、耐震設計の体系上極めて重 要な知見が得られてきた。

免震構造については、上部構造を剛と見なした 1 質点振動采に対 して履歴隇衰型の免震部材を用いた場合が、これに相当し免震部材 の設計において重要な示唆を与えている2)。しかし、1 質点振動系 を用いる限り上部構造の復元力特性を系全体の振動性状一反映する ことはできず、少なくとも2 質点振動系への置換が必要となる。 Ke11y は上部構造を含めた免震構造を 2 質点線形振動系に置換して その定常振動状態について考察を行い、振動モード形状、固有振動 数の分離効果などの免震構造に関する基本的な振動特性を論じてい $ろ^{3)}$ 。免震構造において上部構造の弹塑性性状を考虑した振動性状 を考える場合には、それまで 1 質点非線形振動系、あるいは 2 質点 線形振動系に対して検討されてきた定常振動状態を対象とする解析 的手法の適用は非常に困難となり、既往の研究の多くは時刻歴応答 解析を用いて免震構造の忘答特性に見られる共通性を抽出する方法

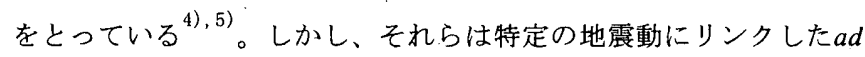
hocな検討結果であり上部構造の非線形性を考慮した場合に免震構 造が本来的に有する振動特性を一般化するには至っていない。

そこで、本研究では免震構造を非線形復元力特性を有する 2 質点 振動系に置き換え、その定常振動状態について考えることによって、 上部構造の非線形性を考慮した免震構造の振動特性を把握する。初 めに、非線形の復元力特性を有する振動系の定常振動応答の解析手 法についてに示す。ここでは既に一般化された知見である 1 質点振 動系の定常振動応答の近似解法を示し、これを 2 質点振動系に拡張 して免震構造への適用を考える。続いて、この近似解法を用いて系 統的なパラメー夕設定の下で数値解析を行い、免震構造の非線形定 常振動応答を基礎固定状態における応答との比較において考察する。 なお、免震構造で用いられるダンパーは粘性系と履歷系の 2 系統に 大別されるが、本論文では粘性系ダンパーを用いた免震構造につい て検討を行うこととする。

\section{2. 非線形定常振動応答の解法 \\ 2. 11 質点振動系の応答}

1 質点振動系の非線形定常振動については既に一般化されている 知見であり、その手法としては線形、非線形の各状態におげる運動
* 北海道大学大学院工学研究科 助教授 - 博士 (工学)

** 清水建設(侏)技術研究所 部長 · 博士 (工学)

*** 北海道大学大学院工学研究科 教授. 工博
Assoc. Prof., Graduate School of Engineering, Hokkaido Univ., Dr. Eng. General Manager, Institute of Technology, Shimizu Corporation, Dr. Eng. Prof., Graduate School of Engineering, Hokkaido Univ., Dr. Eng. 
方程式をたて、境界条件によってそれらを接続する厳密解法 ${ }^{6)}$ ７) と、 非線形定常状態での復元力関数を近似する近似解法 ${ }^{1)}{ }^{1)}$ とに大大別さ れる。厳密解法ではごく限られた条件以外において解析解を求める ことが困難であり、本研究では免震構造への適用を意図した 2 質点 振動系の非線形定常振動への展開を考える場合には近似解法に拠ら ざるを得ないと判断した。そこで、1 質点振動系の定常振動応答の 近似解法として最も一般的かつ実用的であるCaughey の等価線形化 手法 ${ }^{1)}$ を最初に示し、2 質点振動系の非線形定常振動の近似解法へ の定式化の䆃入を図る。

バイリニア型の復元力特性を有する 1 質点振動系を図 1 に示す。 この復元力を線形ばねと完全弾塑性ばねに分離して、完全弾塑性ば ねの復元力を $Q_{n}(u)$ とおくことで、調和地動加速度 $\alpha \cos \omega t$ が作用す る 1 質点振動系の運動方程式は (1) 式のように得られる。

$$
m \ddot{u}+c \dot{u}+k_{e} u+Q_{n}(u)=-m \alpha \cos \omega t
$$

ここで、(1)式における解を近似的に(2) 式のように最大振幅Uの周期 関数であると仮定する。

$$
u=U \cos (\omega t-\varphi)
$$

Caughey は復元力 $Q_{n}(u)$ を等価な線形系の復元力に置換する際に (2)式のように応答の周期性を考虑して、これを等価剛性と等価粘性

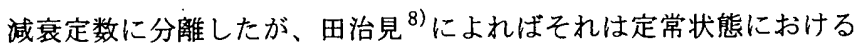
復元力波形をフーリエ級数に展開していることになる。定常状態に おける完全弹塑性ばねの復元力 $Q_{n}$ を、初期剛性 $k_{n}$ と変位関数 $F_{n}$ を 用いて (3) 式のように表現すると、関数 $F_{n}$ は (4) 式のように書ける。

$$
Q_{n}(u)=k_{n} F_{n}(u)
$$

$$
F_{n}(u)=\left\{\begin{array}{ccl}
u-U+U_{y} & \dot{u}<0, & U-2 U_{y}<u<U \\
-U_{y} & \dot{u}<0, & -U<u<U-2 U_{y} \\
u+U-U_{y} & \dot{u}>0, & -U<u<2 U_{y}-U \\
U_{y} & \dot{u}>0, & 2 U_{y}-U<u<U
\end{array}\right.
$$

ここに、 $U_{y}$ は降伏変位である。(2)式において、 $\omega t-\varphi=\theta$ とおき $F_{n}$ を (5)式のように1次までのフーリエ級数で近似すると、フーリエ係数 $C, S$ は (6)，(7)式の積分を実行することで求められる。

$$
\begin{aligned}
& F_{n}(u)=U(C \cos \theta+S \sin \theta) \\
& C=\frac{1}{U \pi} \int_{0}^{2 \pi} F_{n}(u) \cos \theta d \theta \\
& S=\frac{1}{U \pi} \int_{0}^{2 \pi} F_{n}(u) \sin \theta d \theta
\end{aligned}
$$

(6)，(7) 式に(4) 式を代入して演算を実行すると、フーリエ係数 $C, S$ が具体的に(8)，(9)式のように得られる。

$$
\begin{aligned}
& C=\left\{\begin{array}{cc}
\frac{1}{\pi}\left(\theta^{*}-\frac{1}{2} \sin 2 \theta^{*}\right) & U>U_{y} \\
1 & U \leq U_{y}
\end{array}\right. \\
& S=\left\{\begin{array}{cc}
-\frac{1}{\pi} \sin ^{2} \theta^{*} & U>U_{y} \\
0 & U \leq U_{y}
\end{array}\right.
\end{aligned}
$$

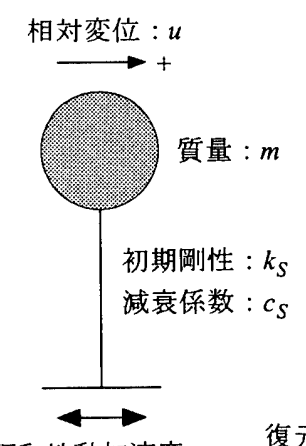

調和地動加速度 : $\alpha \cos \omega t$

復元力の分離 : $Q=Q_{l}+Q_{n}$

$$
\begin{aligned}
& k_{S}=k_{e}+k_{n} \\
& k_{e}=\beta_{y} k_{S} \\
& k_{n}=\left(1-\beta_{y}\right) k_{S}
\end{aligned}
$$

線形ばね

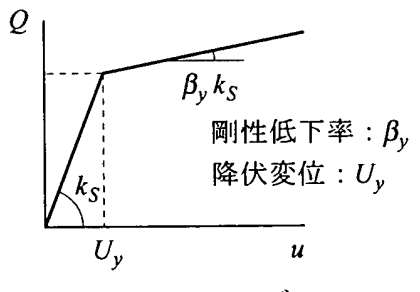

バイリニアモデル

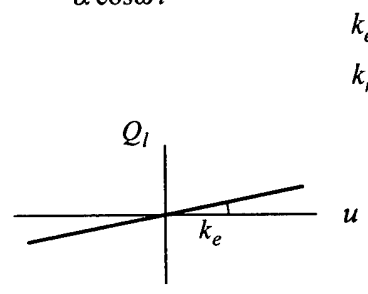

図 1 1 質点振動モデル

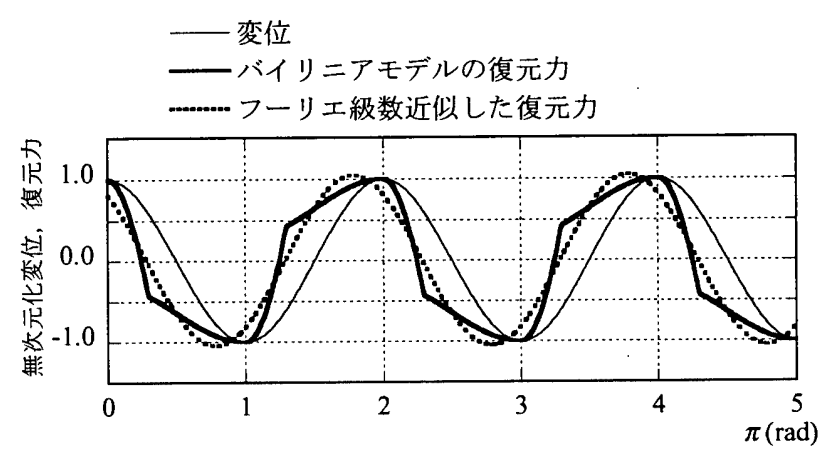

図 2 定常状態における变位・復元力波形の比較

ここに、

$$
\theta^{*}=\cos ^{-1}\left(1-\frac{2 U_{y}}{U}\right)
$$

定常状態における変位波形 $u=U \cos \theta$ のもとで得られるバイリニ アモデルの復元力、およびそれを(8)〜 (10)式に従ってフーリエ級数 近似した復元力を、それぞれ無次元化して比較した結果を図 2 に示 す。塑性化に伴う履歴吸収エネルギーは図 2 のように変位と復元力 との位相差として表現される。また、(10)式からは塑性化の程度に よって位相差が変化することがわかる。

さて、(1) 式に(2)〜 (5) 式を代入して整理すると (11) 式が得られる。

$\left\{-\omega^{2} U+\beta_{y} \omega_{S}^{2} U+\left(1-\beta_{y}\right) \omega_{S}^{2} U C+\alpha \cos \varphi\right\} \cos \theta$

$$
+\left\{-2 h_{S} \omega_{S} U+\left(1-\beta_{y}\right) \omega_{S}^{2} U S-\alpha \sin \varphi\right\} \sin \theta=0
$$

ここに、 $\omega_{S}$ は弾性時の固有円振動数、 $h_{S}$ は弾性時の堿衰定数、 $\beta_{y}$ は 降伏後の剛性低下率であり、 $\omega_{S}, h_{S}$ を以下のように定義する。

$$
\omega_{S}=\sqrt{\frac{k_{S}}{m}}, \quad h_{S}=\frac{c_{S}}{2 m \omega_{S}}
$$


(11)式は恒等式であり、 $\cos \theta, \sin \theta$ の係数をゼロ,とおいた関媇式か ら $\varphi$ を消去すると (12) 式が得られる。

$$
U=\frac{\alpha}{\omega_{S}^{2}} \frac{1}{\sqrt{\left\{\left(1-\beta_{y}\right) C+\beta_{y}-\left(\frac{\omega}{\omega_{S}}\right)^{2}\right\}^{2}+\left\{\left(1-\beta_{y}\right) S-2 h_{S}\left(\frac{\omega}{\omega_{S}}\right)\right\}^{2}}} .
$$

(12) 式に含まれるフーリエ係数 $C, S$ は (8)〜 (10) 式のようにUの関 数である。したがって、振幅Uを求めることは (12) 式の右辺を $f(U)$ とおいた (13) 式を解くことに帰着する。

$$
U-f(U)=0
$$

\section{22 質点振動系の応答}

バイリニア型の復元力特性を有する上部構造と、粘性ダンパーお よび線形アイソレータで構成さ机る免震構造を図 3 に示すような 2 質点振動モデルで表現する。2 質点振動系の非線形定常振動につい ては、1 質点振動系と同様に復元力波形をフーリエ級数展開する近 似解法が田治見 ${ }^{8)}$ により示されているが、本論文ではこの手法を免 震構造へ適用してみる。

図3に示した 2 質点振動モデルに調和地動加速度 $\alpha \cos \omega t$ が作用す るときの運動方程式は、1 質点振動系の場合と同様に上部構造のバ イリニア型の復元力特性を線形ば好と完全弾塑性ばねに分離すると、 各層の相対変位 $u_{1}, u_{2}$ に対して (14)，(15) 式のように得られる。

$$
\begin{aligned}
& m_{2}\left(\ddot{u}_{1}+\ddot{u}_{2}\right)+c_{S} \dot{u}_{2}+k_{e} u_{2}+Q_{n}\left(u_{2}\right)=-m_{2} \alpha \cos \omega t \\
& \left(m_{1}+m_{2}\right) \ddot{u}_{1}+m_{2} \ddot{u}_{1}+c_{D} \dot{u}_{1}+k_{I} u_{1}=-\left(m_{1}+m_{2}\right) \alpha \cos \omega t
\end{aligned}
$$

(14) 式における $Q_{n}\left(u_{2}\right)$ は完全弾塑性ばねの復元力であり、1 質点振 動系の場合と同様に(16)式のように表現する。

$$
Q_{n}\left(u_{2}\right)=k_{n} F_{n}\left(u_{2}\right)
$$

ここで、免震構造の振動特性を表現する新たな変数を以下のように 導入する。

- 基礎固定時の上部構造の固有円振動数 $\omega_{S}$; および減衰定数 $h_{S}$ :

$$
\omega_{S}=\sqrt{\frac{k_{S}}{m_{2}}}, \quad h_{S}=\frac{\dot{c}_{S}}{2 m_{2} \omega_{S}}
$$

・上部構造を剛とした場合のアイソレータのみの固有円振動数 $\omega_{I}$, および粘性ダンパーの減衰定数 $h_{D}$

$$
\omega_{I}=\sqrt{\frac{k_{S}}{m_{1}+m_{2}}}, \quad h_{D}=\frac{c_{D}}{2\left(m_{1}+m_{2}\right) \omega_{I}}
$$

- 質量比 $\gamma$ :

$$
\gamma=\frac{m_{2}}{m_{1}+m_{2}}
$$

（16）式および新たに導入した変数 $\omega_{S}, h_{S}, \omega_{l}, h_{D}$ を(14), (15) 式 に代入して整理すると、(17)，(18)式が得られる。

$$
\begin{aligned}
& \ddot{u}_{1}+\ddot{u}_{2}+2 h_{S} \omega_{S} \dot{u}_{2}+\beta_{y} \omega_{S}^{2} u_{2}+\left(1-\beta_{y}\right) \omega_{S}^{2} F_{n}\left(u_{2}\right)=-\alpha \cos \omega t \\
& \ddot{u}_{1}+\gamma \ddot{u}_{2}+2 h_{D} \omega_{l} \dot{u}_{1}+\omega_{I}^{2} u_{1}=-\alpha \cos \omega t
\end{aligned}
$$

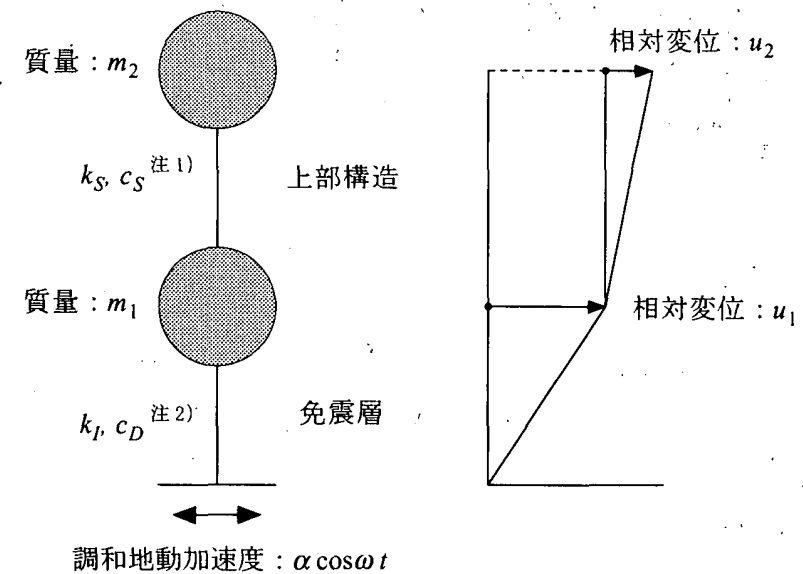

注 1）上部構造のパラメータの定義は 1 質点振動系（図 1 参照）と同じ。 注 2) $k_{1}$ : アイソレータの用性, $c_{D}$ : 粘性系ダンパーの減衰係数

図 32 質点振動モデル

（17），(18）式の解 $u_{1}, u_{2}$ は、定常状態では各層の最大変位振幅を $U_{1}, U_{2}$ として、(19)，(20)式のような周期関数であると仮定する。

$$
\begin{aligned}
& u_{1}=U_{1} \cos \left(\omega t-\varphi_{1}\right) \\
& u_{2}=U_{2} \cos \left(\omega t-\varphi_{2}\right)
\end{aligned}
$$

ここで、新たに $\theta_{2}=\omega t-\varphi_{2}$ なる変数を導入し、 $u_{1}$ を $\theta_{2}$ 使って表現す るために(19)式を(21) 式のように書き換える。

$$
u_{1}=U_{1} \cos \left(\theta_{2}+\varphi_{2}-\varphi_{1}\right)
$$

さらに(16) 式で定義した $F_{n}\left(u_{2}\right)$ を(22) 式のようにフーリエ級数に展 開する。

$$
F_{n}\left(u_{2}\right)=U_{2}\left(C \cos \theta_{2}+S \sin \theta_{2}\right)
$$

（20）（22）式を(17) 式に代入して $\cos \theta_{2}, \sin \theta_{2}$ ごとにまとめると、 (23) 式が得られる。

$$
\begin{array}{r}
\left\{-\omega^{2} U_{2}-\omega^{2} U_{1} \cos \left(\varphi_{2}-\varphi_{1}\right)+\beta_{y} \omega_{S}^{2} U_{2}+\left(1-\beta_{y}\right) \omega_{S}^{2} U_{2} C\right. \\
\left.+\alpha \cos \varphi_{2}\right\} \cos \theta_{2}+\left\{\omega^{2} U_{1} \sin \left(\varphi_{2}-\varphi_{1}\right)-2 h_{S} \omega_{S} \omega U_{2}\right. \\
\left.+\left(1-\beta_{y}\right) \omega_{S}^{2} U_{2} S-\alpha \sin \varphi_{2}\right\} \sin \theta_{2}=0
\end{array}
$$

（23）式は恒等式であり、 $\cos \theta_{2}, \sin \theta_{2}$ の係数をそれぞれゼロとおき、 さらに、 $\cos \varphi+i \sin \varphi=e^{i \varphi}$ を考慮することで、(24) 式が得られる。

$$
\begin{aligned}
-\omega^{2} U_{1} e^{-i \varphi_{1}}+\left\{-\omega^{2}\right. & +2 i h_{S} \omega_{S} \omega+\beta_{y} \omega_{S}^{2} \\
& \left.+\left(1-\beta_{y}\right)(C-i S) \omega_{S}^{2}\right\} U_{2} e^{-i \varphi_{2}}=-\alpha
\end{aligned}
$$

(18)式に対しては、新たに $\theta_{1}=\omega t-\varphi_{1}$ なる変数を導入して $u_{2}$ を $\theta_{1}$ 使って表現するために(20)式を(25)式のように書き換える。

$$
u_{2}=U_{2} \cos \left(\theta_{1}+\varphi_{1}-\varphi_{2}\right)
$$

（19），(25) 式を(18)式に代入しで、(24) 式を得るためと同様の操作を 行うと(26)式が得られる。

$$
\left\{-\omega^{2}+2 i h_{D} \dot{\omega}_{D} \omega+\omega_{I}^{2}\right\} U_{1} e^{-i \varphi_{1}}-\gamma \omega^{2} U_{2} e^{-i \varphi_{2}}=-\alpha
$$


(24)；(26)式は、 $U_{1} e^{-i \varphi_{1}}, U_{2} e^{-i \varphi_{2}}$ に関する連立方程式である。そこ で、(27)式のように行列表示して解を求める。

$$
\left\{\begin{array}{l}
U_{1} e^{-i \varphi_{1}} \\
U_{2} e^{-i \varphi_{2}}
\end{array}\right\}=\left[\begin{array}{ll}
A_{11} & A_{12} \\
A_{21} & A_{22}
\end{array}\right]^{-1}\left\{\begin{array}{l}
-\alpha \\
-\alpha
\end{array}\right\}
$$

ここに、

$$
\begin{aligned}
& A_{11}=-\omega^{2} \\
& A_{12}=-\omega^{2}+2 i h_{S} \omega_{S} \omega+\beta_{y} \omega_{S}^{2}+\left(1-\beta_{y}\right)(C-i S) \omega_{S}^{2} \\
& A_{21}=-\omega^{2}+2 i h_{D} \omega_{D} \omega+\omega_{I}^{2} \\
& A_{22}=-\gamma \omega^{2}
\end{aligned}
$$

$A_{12}, A_{21}$ は複素数であり、(28)〜 (30)式の演算結果をそれぞれ実部と 虚部に分離して表現する。

$$
\begin{aligned}
& A_{11} A_{22}-A_{12} A_{21}=R_{0}+i I_{0} \\
& A_{22}-A_{12}=R_{1}+i I_{1} \\
& -A_{21}+A_{11}=R_{2}+i I_{2}
\end{aligned}
$$

以上から $U_{1} e^{-i \varphi_{1}}, U_{2} e^{-i \varphi_{2}}$ が (31)，(32) 式のように得られる。

$$
\begin{aligned}
& U_{1} e^{-i \varphi_{1}}=-\frac{R_{1}+i I_{1}}{R_{0}+i I_{0}} \alpha \\
& U_{2} e^{-i \varphi_{2}}=-\frac{R_{2}+i I_{2}}{R_{0}+i I_{0}} \alpha
\end{aligned}
$$

さらに、振幅のみに着目して各層の振幅 $U_{1}, U_{2}$ が(33)，(34)式のよ うに得られる。

$$
\begin{aligned}
& U_{1}=\alpha \sqrt{\frac{R_{1}^{2}+I_{1}^{2}}{R_{0}^{2}+I_{0}^{2}}} \\
& U_{2}=\alpha \sqrt{\frac{R_{2}^{2}+I_{2}^{2}}{R_{0}^{2}+I_{0}^{2}}}
\end{aligned}
$$

上式の中で、 $R_{0}^{2}+I_{0}^{2}, R_{1}^{2}+I_{1}^{2}$ にはフーリエ係数 $C, S$ が含まれ、そ

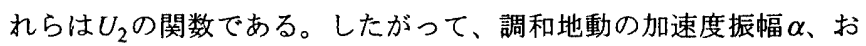
よび振動数 $\omega$ に対する $U_{1}, U_{2}$ を求めるには、初めに $U_{2}$ のみの関数 である (34) 式から $U_{2}$ を求め、これを(33) 式に代入して $U_{1}$ を求める 方法が妥当である。ただし、(34) 式は $U_{2}$ について代数的に解くこと ができない超越方程式となる。よって、 $U_{2}$ を求めることは、(34) 式 中にある $R_{0}^{2}+I_{0}^{2}$ を $U_{2}$ の関数 $g\left(U_{2}\right)$ であると表現して書き換えた (35) 式を数値的に解く問題に帰着する。

$$
U_{2}-\alpha \sqrt{\frac{R_{2}^{2}+I_{2}^{2}}{g\left(U_{2}\right)}}=0
$$

\section{3. 数值解析と考察}

\section{1. 解析パラメータの設定}

免震構造には多様なパラメータの組み合わせが想定できるが、本 研究では結果の一般化を意図して、極力それらを無次元化すること を考える。例えば上部構造の降伏耐力と調和地動の加速度振幅との 大小関倸は応答值に対して相対的なものである。よって、上部構造 の降伏耐力に対応する加速度として (36) 式のように降伏点加速度 $\alpha_{S}$
を定義し、これと調和地動加速度振幅 $\alpha$ との比、寸なわち降伏点加 速度比 $\alpha_{S} / \alpha$ を用いて上部構造の降伏耐力と調和地動加速度との相対 関倸を無次元化して考えることとする。

$$
\alpha_{S}=\frac{k_{S} U_{y}}{m_{2}}
$$

さらに、上部構造の降伏後剛性は弹性剛性に対する比である剛性 低下率（図 1 参照）として、調和地動振動数 $\omega$ は構造物の固有振動 数（基礎固定では $\omega_{S}$ 、免震構造では $\omega_{I}$ ) との比（加振振動数比 $\omega_{S}$ ' $\omega$, あるいは $\left.\omega_{I} / \omega\right)$ として、免震構造における免震層の㴊性と上部構 造の剛性との関係は固有振動数比 $\left(\omega_{S} / \omega_{I}\right)$ として考える。その他、 図 3 に示した 2 質点振動モデルを表現するパラメータを含め、本研 究では以下のように解析パラメータの值を設定する。

·上部構造の減衰定数 $: h_{S}=0.01$ （固定）

-免震層の粘性ダンパーの堿衰定数 : $h_{D}=0.15$ （固定）

-上部構造の降伏点加速度比 : $\alpha_{S} / \alpha=1.0 \sim 5.0$

·上部構造の剛性低下率 : $\beta_{y}=0.1 \sim 1.0$

- 加振振動数比 : $\omega / \omega_{I}=0.0 \sim 2.0$ (免震構造の場合） $\omega / \omega_{S}=0.0 \sim 2.0$ (基礎固定の場合）

·上部構造と免震層と固有振動数比 : $\omega_{S} / \omega_{I}=0.0 \sim 10.0$

·質量比 : $\gamma=0.5 \sim 0.9$

本研究では、以上のパラメータ設定值に対して得られる定常応答 において、変位応答値に着目して検討を進める。具体的には、上部 構造の応答変位は振幅 $U_{2}$ を降伏変形 $U_{y}$ に対する比（塑性率）とし て、また兔震層の応答変位は振幅 $U_{1}$ を静的変形 $U_{1 s}$ に対する比（静 的変形倍率）として無次元化して考察を行う。なお、免震層の静的 変形 $U_{1 s}$ は(37) 式のように定義する。

$$
U_{1 s}=\frac{\alpha\left(m_{1}+m_{2}\right)}{k_{I}}
$$

免震構造の上部構造の定常応答について考察する際に、比較の対 象とする基礎固定状態はこれを 1 質点振動系と見なして（12）式に よって応答值を求める。1 質点振動系および 2 質点振動系において それぞれ解くべき方程式 (13)，(35) 式は、いずれも変位振幅 $U$ に関 する超越方程式である。また、微分ができないことから 2 分法を適 用して数值的に変位振幅 $U$ を解く。

\section{2 共振曲線の考察}

初めに、固有振動数比を $\omega_{S} / \omega_{I}=5.0$ 、質量比を $\gamma=0.75$ と固定し、 上部構造の降伏後の剛性低下率を 3 通り $\left(\beta_{y}=0.1,0.2,0.5\right)$ に変化さ せた場合の応答変位について、基礎固定状態の共振曲線を図4に、免 震構造における上部構造および免震層の共振曲線を図 5 、図 6 に示 す。これらの図では上部構造の降伏点加速度比 $\alpha_{S} / \alpha$ を $1.0 \sim 5.0$ の 範囲で 0.25 刻みで変化させた場合の共振曲線を重ね描いている。

上部構造の共振曲線について基礎固定と免震構造を比較すると、 $\alpha_{S} / \alpha か ゙$ 減少する、すなわち降伏耐力を低減させるあるいは入力加速 度が增大するに従って、基礎固定では共振曲線のピークとなる共振 振動数は低下するが、免震構造では共振振動数の变化は少ない。基 礎固定における共振振動数の低下は、塑性化の進行によって㴊性低 下が生じることが原因である。しかし、免震構造では上部構造の塑 性化によって剛性低下が生じても系全体の振動特性への影響が少な い。免震構造において上部構造が塑性化し剛性低下した状況におい 

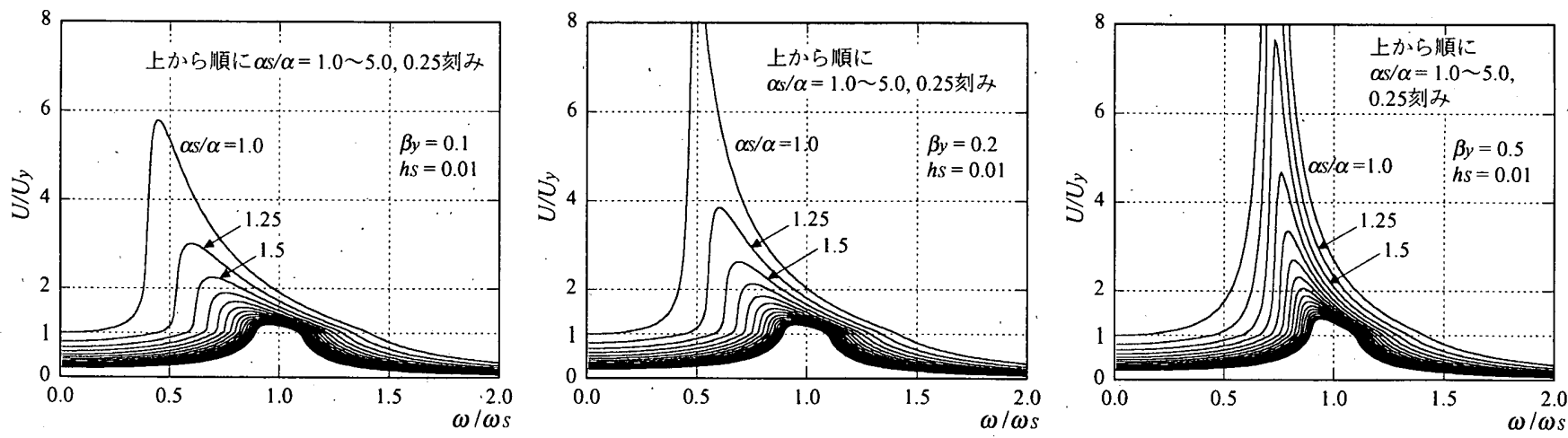

図 4 基礎固定の共振曲線（左 : $\beta_{y}=0.1$, 中央 : $\beta_{y}=0.2$, 右 : $\beta_{y}=0.5$ ）
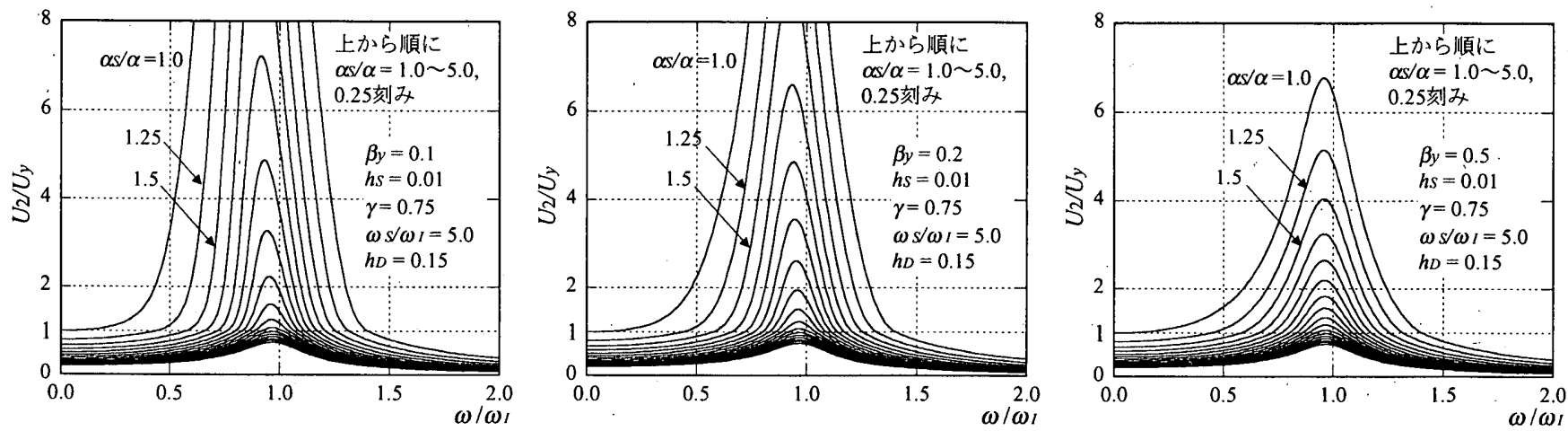

図 5 免震構造における上部構造の共振曲線（左: $\beta_{y}=0.1$, 中央 : $\beta_{y}=0.2$, 右: $\beta_{y}=0.5$ )
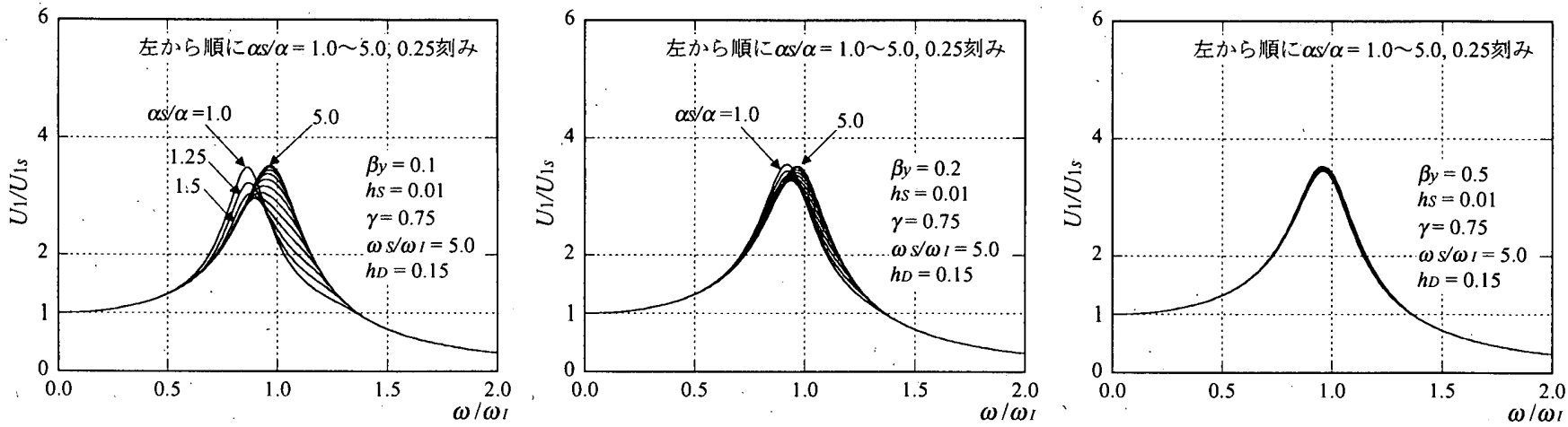

図 6 免震構造における免震層の共振曲線（左 : $\beta_{y}=0.1$, 中央 : $\beta_{y}=0.2$, 右 : $\beta_{y}=0.5$ ）

ても 1 次モードが卓越するような免震層と上部構造との剛性比が確 保されている場合には、Kelly ${ }^{3)}$ が論じているように固有振動数の分

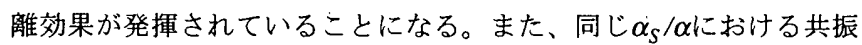
曲線を比較すると、降伏後の剛性低下が少ない、寸なわち剛性低下 率が大きいほど基礎固定では応答変位が増大するが、免震構造では 逆に応答变位が減少する。

一方、免震層の共振曲線については、上部構造に見られるほどの 変化はなく、最も変動が大きな場合でも上部構造の㴊性低下率が $\beta_{y}=0.1$ において共振曲線のピーク值に約 $20 \%$ 程度の変動が見られる 程度である。すなわち、上部構造の塑性化はあまり免震層の応答変 位には影響を及ぼさないことがわかる。

以上、上部構造に関するパラメータとして降伏点加速度比 $\alpha_{S} / \alpha$, 㴊性低下率 $\beta_{y}$ を変化させた場合の忘答変位に関する共振曲線を例示
してそれらの変化について考察したが、以下では $\alpha_{S} / \alpha, \beta_{y}$ を含め 図 3 に示した 2 質点振動モデルの各パラメータが上部構造の応答変 位に及ぼす影響について個々に検討を行う。ただし、すべてのパラ メータを同時に変動させた共振曲線群を示すことはできないため、 共振曲線のピーク值に着目し特定のパラメータのみを変動させて、 それが上部構造の応答塑性率に及ほす影響について検討する。

\section{3 上部構造の降伏耐力と剛性低下率の影響}

上部構造の剛性低下率を一定とし降伏点加速度比を変化させた場 合の共振曲線群から、共振時の加振振動数比 $\left(\omega_{\text {peak }} / \omega_{S}, \omega_{\text {peak }} / \omega_{l}\right)$ を 求めた結果を図 7 に、その時の上部構造の塑性率の变化を図 8 に示 す。図 7 からは基礎固定では最も剛性低下が著しい状態において弾 性時の $50 \%$ 程度まで共振振動数が低下寸るが、免震構造では $10 \%$ 程 


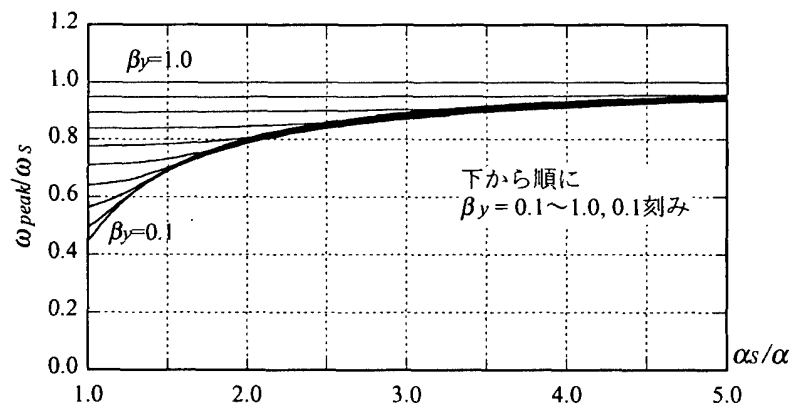

（a）基䃂固定

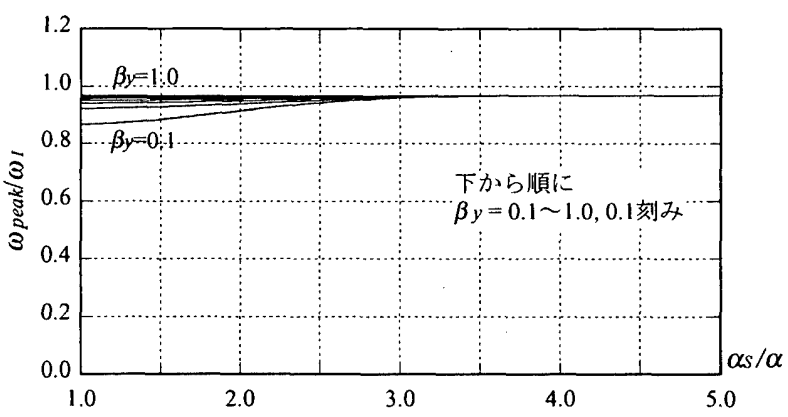

（b）免震構造

図 7 上部構造の降伏耐力と共振振動数の関係

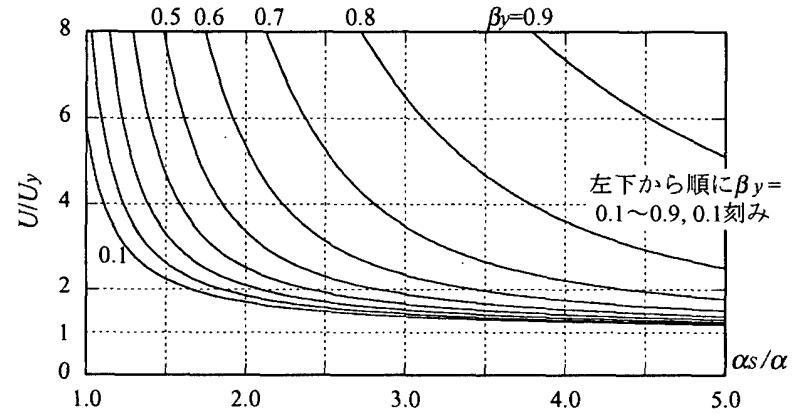

(a). 基礎固定

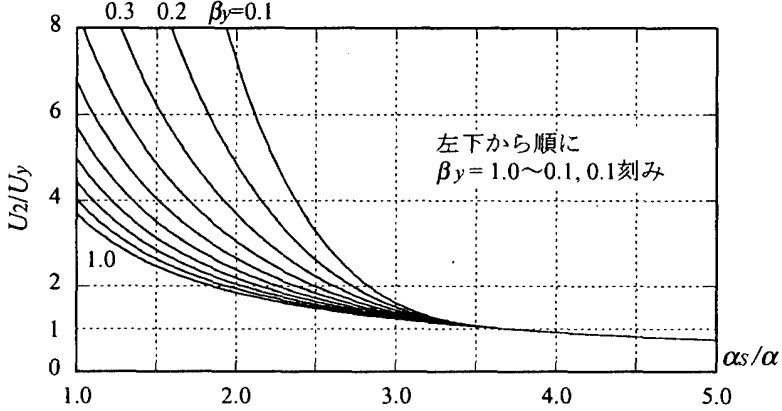

（b）免震構造

図 8 上部構造の降伏耐力と塑性率の関倸

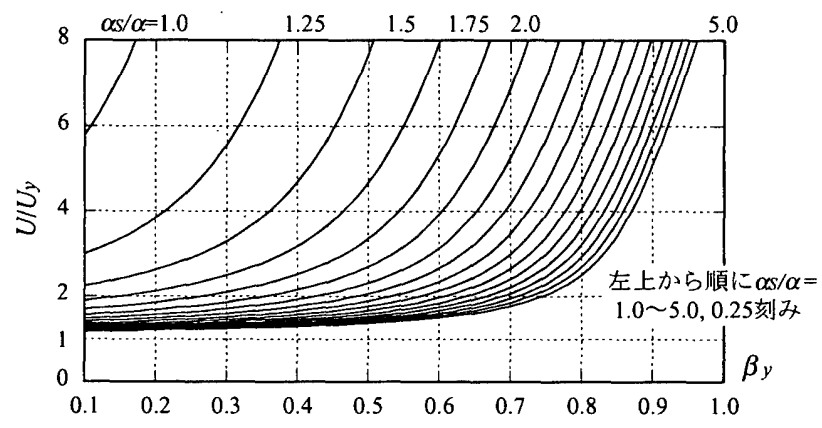

(a) 基礎固定

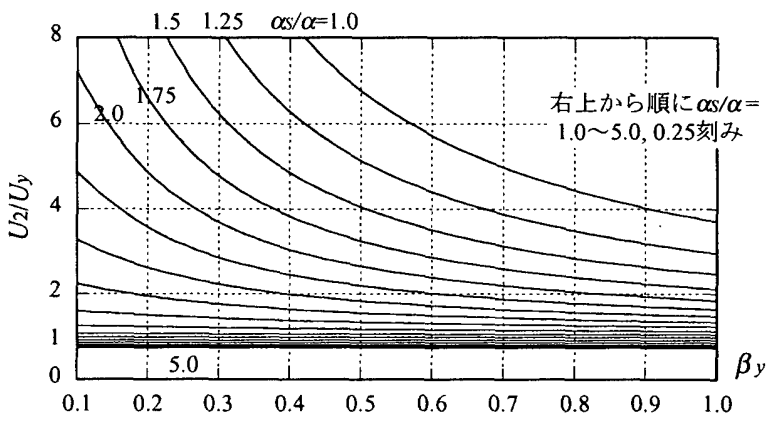

(b) 免震構造

図 9 上部構造の剛性低下率と塑性率の関倸

度しか共振振動数は低下しないことがわかる。図 8 における上部構 造の降伏耐力と塑性率関係では、いずれの曲線も右下がりとなって おり、降伏耐力を低减させると塑性率が増大する傾向は基礎固定と 免震構造で同じである。しかし、剛性低下率 $\beta_{y}$ とそれに対応する曲 線群の上下関保が基礎固定と免震構造では全く逆となっている。す なわち、基礎固定では凮性低下率が小さいほど塑性率は低減するが、 免震構造では逆に塑性率は增大することがわかる。免震棈造では $\alpha_{S}$ $/ \alpha=3.5$ 以上において塑性率が 1.0 を下回り、上部構造が弾性状態を 維持している点において免震効果を見出すことができる。しかし、 $\alpha_{S} / \alpha=3.5$ 以下では塑性化が生じた段階で塑性率が増大し、剛性低 下率が小さいほど塑性率は急激に増大する傾向が強くなる。

続いて、上部構造の降伏耐力を一定とし剛性低下率を変化させた 共振曲線群から共振時の塑性率を求めた結果を図 9 に示す。基礎固
定と免震構造では曲線群の傾きが逆となっていることは非常に興味 深い。降伏耐力を一定とした場合、剛性低下率が小さいほど、すな わち剛性が大きく低下するほど基礎固定では塑性率が小さくなるの に対して、免震構造では逆に塑性率が大きくなる。

図8、図9に示した結果のうち基礎固定における上述の傾向は、こ れまでにも 1 質点振動系における非線形定常振動に関する研究 ${ }^{1) ， 7)}$ ，8) で論じられているように、構造物の塑性化の進行に伴って履歴減 衰が有効に作用して応答変位が低減されることと理解できる。これ は、現行の耐震設計において構造特性係数 $D s$ 值が規定されている所 以でもある。しかし、本研究で得られた一連の解析結果からは、免 震構造における上部構造の塑性化は必ずしも応答变位の低減効果と はならず、単に応答変位の増大となって現れていることがわかる。 免震構造の上部構造は、免震層のフィルター効果により基礎固定と 


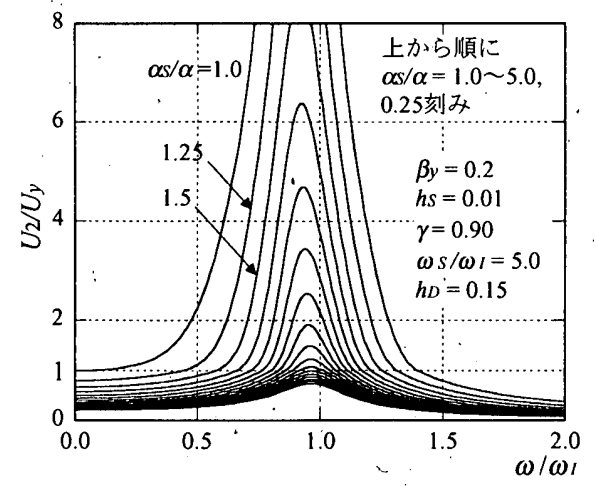

図 10 免震構造における上部構造の共振曲線 （質量比 $\gamma=0.9$ とした場合）

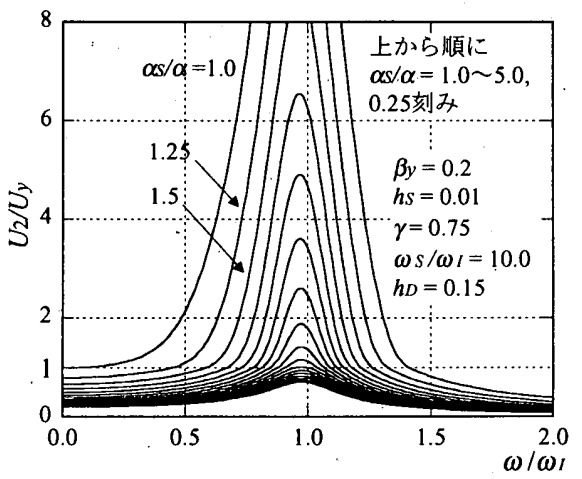

図 12 免震構造における上部構造の共振曲線 （固有振動数比 $\omega_{S} / \omega_{I}=10.0$ とした場合）

した上部構造の固有振動数よりも低い振動数で加振されることとな る。これは図 4 に示した基礎固定の共振曲線における加振振動数比 の低い領域にあり静的に近い加振状態とみなせる。静的加力状態で は構造物の剛性のみが变形を抑制し、上部構造が塑性化した後の剛 性低下は変形の増大しかもたらさない。実際の構造物では塑性化の 進行に伴って徐々に剛性低下していくことから、塑性化の進行を剛 性低下率の减少に関連付けて考えると、以上の考察結果は、免震構 造では上部構造の塑性化の進行が応答変位の増大を導き、さらなる 塑性化の進行をもたらす可能性を示唆するものであると解釈できる。

\section{4 質量比と固有振動数比の影響}

図 7 〜図 9 に示した解析結果において、免震構造では 2 質点振動 系のパラメータのうち質量比を $\gamma=0.75$ 、固有振動数比を $\omega_{S} / \omega_{l}=5.0$ と固定したが、上述の考察結果が本研究で対象とする粘性系ダン パーを用いた免震構造において一般的に見られる傾向であることを 示すために、質量比あるいは固有振動数比を変動させた場合につい て検討する。

図 10 は図 5、図6 で共振曲線を示した免震構造のうち上部構造の 剛性低下率 $\beta_{y}=0.2$ について、質量比を $\gamma=0.90$ に変更した場合の 上部構造の共振曲線である。また、図 11 は同じく $\beta_{y}=0.2$ について 質量比を $\gamma=0.5 \sim 0.9$ の範囲で連続的に変化させた場合の共振時の 上部構造の塑性率を求めた結果である。図 10 の共振曲線は塑性率 1.0 以上において曲線群の間隔が疎となり塑性化すると応答変位が 急激に増大することは、 $\gamma=0.75$ とした図 5 の共振曲線と概ね同じ傾

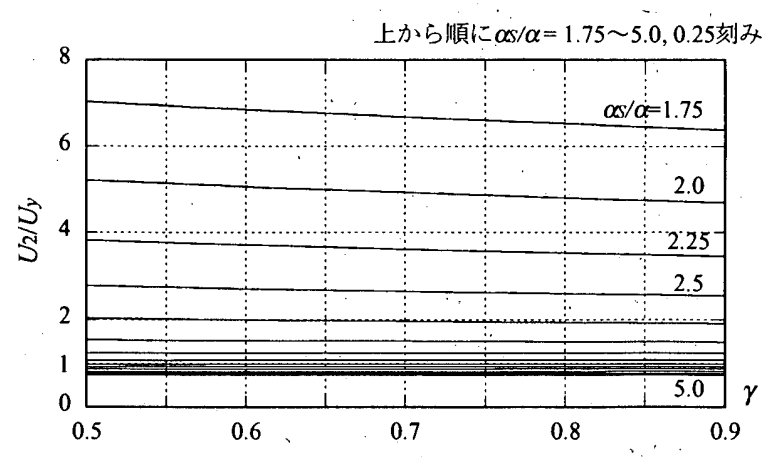

図 11 質量比と上部構造の塑性率の関係

$\left(\beta_{y}=0.2, h_{S}=0.01, \omega_{S} / \omega_{I}=5.0 ; h_{D}=0.15\right)$

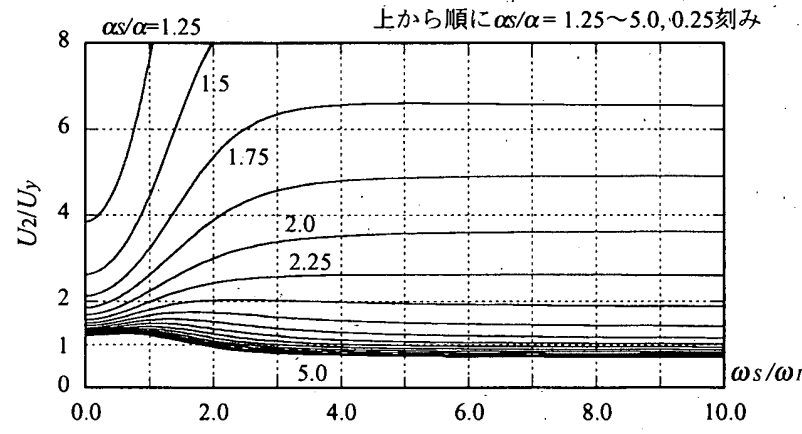

図 13 固有振動数比と上部構造の塑性率の関係 $\left(\beta_{y}=0.2, h_{S}=0.01, \gamma=0.75, h_{D}=0.15\right)$

向を示している。また、図11からは、質量比と上部構造の塑性率の 関係を示す曲線群の傾きは非常に小さく、質量比によらず上部構造 はほほ同じ応答変位を示すことがわかる。

図 12 は図 5、図 6 で共振曲線を示した免震構造のうち上部構造の 剛性低下率 $\beta_{y}=0.2$ について、固有振動数比を $\omega_{S} / \omega_{I}=10.0$ に変更し た場合の上部構造の共振曲線である。また、図 13 は同じく $\beta_{y}=0.2$ について固有振動数比を $\omega_{S} / \omega_{I}=0.0 \sim 10.0$ の範囲で連続的に変化 させた場合の共振時の上部構造の塑性率を求めた結果である。図 13

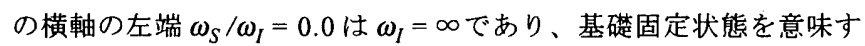
る。図 12 の共振曲線を見ると、塑性率 1.0 以上において曲線群の間 隔が疎となり、 $\omega_{S} / \omega_{I}=5.0$ とした図 5 の共振曲線と概ね同じ傾向を 示している。図 13 からは固有振動数比が $\omega_{S} / \omega_{I}=4.0$ 以上では固有 振動数比によらず上部構造の塑性率はほぼ一定となる。免震構造の 領域を固有振動数比でみると、例えば基礎固定時の固有周期が 1.0 秒となる上部構造に対して免震時の周期を 4.0 秒に設定すると固有 振動数比は $\omega_{S} / \omega_{I}=4.0$ となる。図 13 において $\omega_{S} / \omega_{I}=4.0$ 以上に見 られるような上部構造の塑性率がほぼ一定となる領域は十分に免震 構造と見なせる領域である。よって、先述の図 7 図 9 に関する考 察結果は、粘性系ダンパーを用いた免震構造の一般的な振動特性で あると言える。

\section{4. 結論}

本研究では粘性系ダンパーを用いた免震構造における上部構造の 非線形性を考慮した振動特性を把握する目的から、これを 2 質点振 
動系に置換して非線形定常振動応答について考察した。その結果、 免震構造の上部構造は塑性化すると急激に応答変位が增大し、上部 構造の塑性化に伴う履歴エネルギー吸収によって応答変位が低減す る効果は期待できないことが明らかとなった。免震構造の非線形定 常振動性状が、1 質点振動系に置換した基礎固定状態のそれとは全 く異なることは非常に興味深い。著者らは、本研究における考察結 果と同様の傾向を多数の地震応答解析結果からも経験的に見出して

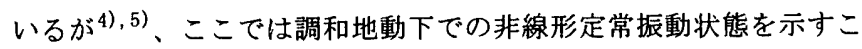
とで理論的な検証を行ない、このような振動特性を一般化した。

通常、免震構造を採用すれば上部構造の応答变位は基䃈固定時よ りも低减され、従来よりも小さな設計用地震力のもとで設計が行わ れる。上部構造の塑性化は、降伏耐力と入力地震動レベルの相対的 な大小関倸において、降伏耐力の過度の低减あるいは予想以上の地 震入力のいずれかによってもたらされる。現実的には免震構造の上 部構造を積極的に塑性化させる設計は考えられないものの、免震構 造が潜在的に有するこのような振動特性を踏まえておくことが、免 震構造の設計において重要であると考える。極論的には、免震構造 の上部構造を塑性化させることは在来構造と比較して危険であり、
低勒性であっても塑性化させない設計を第一に考えるべきである。 なお、本研究では粘性系ダンパーを用いた免震構造を対象とした が、もう一方の主要な免震システムである履歷系ダンパーを用いた 免震構造の非線形定常振動応答についても今後検討を加える必要が ある。

\section{参考文献}

1) T. K. Caughey, 'Sinusoidal Excitation of a System With Bilinear Hysteresis', Journal of Applied Mechanics, 640-643, Dec. 1960. 2）日本建築学会, 免震構造設計指針, 1993年版

3) J. M. Kelly, 'Base Isolation: Linear Theory and Design', Earthquake Spectra, Vol. 6, No. 2, 223-244, 1990.

4）田村和夫, 㐘地優: 免震 RC 造骨組の弹塑性応答性状, 日本建築学会大会 学術講演梗概集（構造 II），pp. 651-652， 1990.

5）菊地優，田村和夫，和田章:免震構造物の安全性評価に関する一考察，日 本建築学会構造系論文集，第 470 号, pp. 65-73，1995.4.

6) J. P. Den Hartog, 'Forced Vibrations With Combined Coulomb and Viscous Friction, Transactions', ASME, APM-53-9, 107-115, 1931.

7）梅村魁，建築耐震論，彰国社， 1968.

8）田治見宏, 建築振動学、コロナ社, 1965.

（2003年 8 月 27 日原稿受理，2003年11月 14 日採用決定） 